УДК: 657.635

JEL Classification: М 42

Н. І. ДОРОШ,

доктор економічних наук, професор кафедри обліку та аудиту,

Київський національний університет імені Тараса Шевченка;

M. О. ФЕСАЙ, магістрант,

Київський національний університет імені Тараса Шевченка

\title{
Методологічні аспекти оцінки аудитором внутрішнього контролю на підприємстві
}

У статті розкрито методологічні аспекти оцінювання аудитором внутрішнього контролю на підприємстві за стадіями аудиторського процесу. Висвітлено методику аудиту та адекватності розробки ефективності функціонування внутрішнього контролю на підприємстві за окремими бізнес-прочесами. Розкрито значення внутрішнього контролю окремих бізнес-прочесів підприємства. Показано вплив очінки внутрішнього контролю на підприємстві на планування наступних аудиторських прочедур по суті.

Ключові слова: внутрішній контроль на підприємстві, бізнес-процес, адекватність розробки внутрішнього контролю, ефективність функиіонування внутрішнього контролю, фінансова звітність, ризик.

Постановка проблеми. Сучасний розвиток аудиту потребує оптимізації та підвищення якості аудиторської перевірки на всіх етапах ії здійснення. Перевірка аудиторами адекватності розробки внутрішнього контролю на підприємстві є однією із найважливіших аудиторських процедур, необхідних для підтвердження достовірності фінансової звітності.

Актуальність теми обумовлюється необхідністю формування єдиної методології оцінювання зовнішнім аудитором дієвості системи внутрішнього контролю суб' єктів господарювання з метою підвищення ефективності аудиторської перевірки та виокремлення важливих ділянок обліку, які можуть мати значний вплив на формування фінансової звітності, а також встановлення для них аудиторських процедур по суті.

Метою статті $\epsilon$ розкриття методологічних аспектів оцінювання аудиторами системи внутрішнього контролю на підприємстві. Для досягнення зазначеної мети поставлено завдання:

- визначити місце оцінювання внутрішнього контролю на підприємстві в процесі аудиту фінансової звітності;

- $\quad$ розкрити поняття бізнес-процесів підприємства, а також методику виявлення ризиків суттєвого викривлення інформації щодо них та встановлення окремих засобів контролю в загальній організаційній структурі;

- узагальнити прийоми тестування внутрішнього контролю на підприємстві, розкривши сутність тестування на адекватність розробки та ефективності функціонування внутрішнього контролю на підприємстві;

- розкрити вплив оцінки внутрішнього контролю на підприємстві на планування аудиторських процедур по суті.

Об 'єктом дослідження є процеси оцінювання внутрішнього контролю на підприємстві в системі аудиторської перевірки. Предмет дослідження - теоретичні та методологічні аспекти проведення аудиту на етапі оцінювання внутрішнього контролю на підприємстві.

Аналіз останніх досліджень і публікацій. Вагомий внесок у розвиток теоретичних основ та проблематики аудиту внутрішнього контролю здійснили: Н. Дорош, С. Бардаш, В. Головач, Т. Камінська, В. Рудницький, Н. Шалімова, М. Шигун, В. Пантелеєв, О. Редько та інші. Разом із тим, слід відзначити, що окремі питання організації та

(C) Н. I. Дорош, М. О. Фесай, 2018 
методики аудиту внутрішнього контролю залишаються невирішеними, потребують подальшого дослідження та впровадження в практику діяльності вітчизняних аудиторських фірм. Зокрема, таким важливим аспектом $є$ аудит системи внутрішнього контролю на підприємстві за окремими бізнес-процесами.

Методологія дослідження. У процесі дослідження методології аудиту внутрішнього контролю на підприємстві використано загальнонаукові та специфічні методи дослідження, такі як узагальнення, порівняння, аналіз та синтез, дедукція та індукція, а також проаналізовано досвід міжнародної практики аудиту для гармонізації з нею сучасних реалій вітчизняного аудиту.

Виклад основного матеріалу. Система внутрішнього контролю на підприємстві являє собою процес, що здійснюється радою директорів, керівництвом та іншим персоналом організації з метою визначення подій, які можуть впливати на підприємство та управління, пов'язаних із цими подіями ризиків, а також контроль забезпечення гарантії досягнення цілей підприємства [10, с.17].

Згідно з МСА 315 "Ідентифікація та оцінювання ризиків суттєвого викривлення через розуміння суб'єкта господарювання і його середовища” внутрішній контроль - це процес, розроблений, запроваджений і підтримуваний тими, кого наділено найвищими повноваженнями, управлінським персоналом, а також іншими працівниками, для забезпечення достатньої впевненості щодо досягнення цілей суб'єкта господарювання стосовно достовірності фінансового звітування, ефективності та результативності діяльності, а також дотримання застосовних законів і нормативних актів. Термін "заходи контролю” стосується кожного окремого аспекту одного чи кількох компонентів системи внутрішнього контролю [1, с. 290].

Відповідно до інтегрованої моделі COSO ERM, система внутрішнього контролю 3-поміж ряду елементів, таких як внутрішнє середовище, постановка цілей, контрольні заходи, організація інформаційного та комунікаційного обміну, здійснення моніторингу, також включає такі важливі складові як ідентифікація ризиків, їх оцінювання та управління ними [3, с. 32]. Управління ризиками підприємства - це процес, який починається з розробленням стратегії підприємства і торкається всієї діяльності підприємства. Він спрямований на визначення подій, які можуть впливати на підприємство, та ризиків, пов'язаних з цими подіями [4, с. 16].

Аудит системи внутрішнього контролю на підприємстві, який здійснюється за окремими бізнес-процесами, передбачає перевірку забезпечення ефективності управління ризиками суб'єкта господарювання щодо таких бізнес-процесів протягом певного періоду часу, як складового елемента системи внутрішнього контролю.

Комплексна аудиторська перевірка системи внутрішнього контролю на підприємстві щодо достовірності фінансової звітності у всіх суттєвих аспектах включає проведення аудиторами тестування внутрішнього контролю для досягнення основних цілей, які полягають в отриманні таких достатніх доказів:

- підтвердження думки аудитора щодо прийнятності рівня розробки та дієвості внутрішнього контролю фінансової звітності;

- адекватності аудиторської оцінки ризику контролю для цілей аудиту фінансової звітності.

Аудит адекватності розробки та ефективності функціонування внутрішнього контролю на підприємстві доцільно здійснювати щодо основних бізнес-процесів підприємства. 3 погляду на послідовність етапів процесу аудиту (рис. 1), які мають свої особливості, доцільним $є$ їх детальний розгляд та виокремлення ключових правил та принципів, якими керуються аудитори під час їх здійснення.

Етап розуміння бізнес-процесу і його основних господарських операцій, сукупність яких представляє бізнес суб'єкта господарювання в цілому, неможливо побудувати правильно без поняття “бізнес-процес". Бізнес-процеси підприємства це операції, які забезпечують проектування, виробництво і реалізацію товарів, робіт чи послуг підприємства. Крім традиційного підходу до визначення основних бізнес-процесів, у сучасних умовах до них включають належне ведення обліку та складання фінансової звітності, а також дотримання законів і правил щодо фінансової звітності [5] 


\begin{tabular}{|c|c|}
\hline \multirow{3}{*}{ Розуміння процесу } & Розуміння бізнес-процесу та його основних господарських операцій \\
\hline & $\begin{array}{c}\text { Виявлення ризиків суб’єкта господарювання та суттєвого } \\
\text { викривлення інформації щодо окремих бізнес-процесів }\end{array}$ \\
\hline & $\begin{array}{c}\text { 3'ясування засобів контролю, який виконується управлінським } \\
\text { персоналом, для покриття ризиків }\end{array}$ \\
\hline \multirow{5}{*}{ Тести контролю } & Тести адекватності розробки внутрішнього контролю \\
\hline & Попередня оцінка ризику контролю \\
\hline & $\begin{array}{c}\text { Планування тестів ефективності функціонування внутрішнього } \\
\text { контролю }\end{array}$ \\
\hline & Виконання тестів операційної ефективності \\
\hline & Оцінка операційної ефективності та ризику контролю \\
\hline \multirow{3}{*}{ Процедури по суті } & Планування суті, термінів та обсягу процедур по суті \\
\hline & Виконання процедур по суті \\
\hline & Оцінка отриманих результатів процедур по суті \\
\hline \multirow{3}{*}{$\begin{array}{c}\text { Узагальнення доказів } \\
\text { та формування } \\
\text { висновків }\end{array}$} & Узагальнення отриманих аудиторських доказів \\
\hline & Оцінювання доказів та формування аудиторського звіту \\
\hline & $\begin{array}{c}\text { Складання висновку про ефективність системи внутрішнього } \\
\text { контролю }\end{array}$ \\
\hline
\end{tabular}

\section{Рис. 1. Етапи процесу аудиту фінансової звітності за окремими бізнес-процесами}

Джерело: складено авторами

Кожен бізнес-процес складається із певного набору відповідних йому операцій, які обумовлюють їх облік та формування фінансової звітності. Так, процес реалізації включає оброблення замовлення на купівлю, оформлення відповідних документів про відвантаження, авторизацію оброблених даних відповідальними особами, проведення оплати покупцем. Цикл цих операцій підлягає належній реєстрації та обліковому відображенню.

Для повного розуміння бізнес-процесу і його основних господарських операцій під час здійснення аудиторської перевірки фінансової звітності аудитор повинен вивчити такі ключові аспекти:

- основні бізнес-процеси та потоки операцій підприємства, інформація про які потрібна для проведення подальших аудиторських процедур з метою підтвердження достовірності фінансової звітності;

- ризики, пов'язані зі здійсненням бізнес-процесів та операцій на підприємстві;

- характер інформаційних процесів на підприємстві, включаючи програмне забезпечення та інформаційно-технологічне середовище, а також розподіл обов'язків персоналу всередині інформаційного середовища.

Важливим для аудиторської перевірки є розмежування між поняттями “бізнеспроцес”, який описує порядок здійснення операції за допомогою встановлених етапів, та “контроль", який передбачає сукупність дій та заходів, спрямованих на попередження або виявлення невідповідностей у процесі. Наприклад, бізнес-процесом є вибір і документування обліковцем відповідної моделі оподаткування прибутку, яка використовуватиметься для реалізації договору купівлі-продажу, а контролем - перегляд і підтвердження контролером звіту про визнання доходів. При цьому контролер вивчає 
всі умови договору та керується законодавчою базою і професійними стандартами, а також, в окремих випадках, переглядає та змінює результати оподаткування.

Аудитор починає ознайомлення з бізнес-процесом із відстеження операцій, які йому відповідають, та ризиків, які його супроводжують, а також внутрішнього контролю підприємства щодо них.

Оформлення аудитором розуміння бізнес-процесу починається з його детального розгляду у вигляді покрокового описання виконання операцій від етапу їх виникнення в середовищі бізнес-процесу, включаючи інформаційні системи, до відображення їх у фінансових звітах підприємства [10, с. 10].

Для опису бізнес-процесів аудитор використовує документацію підприємства щодо них, зокрема описи бізнесу підприємства, технологічні стадії виконання операцій та реєстр ризиків суттєвого викривлення, що формується на підприємстві для цілей внутрішнього контролю за процесами підприємства, ризиками, які їм відповідають, їх наслідками, із зазначеннями походження інформації про ризик [8].

Після отримання належної інформації та документів від підприємства розпочинається етап оновлення технологічної документації та перевірка адекватності їі розробки підприємством. На основі цих дій оновлюється ризик суттєвого викривлення для аудиторської перевірки поточного року.

Для якісного розуміння аудитор відображає потоки операцій у вигляді технологічних схем бізнес-процесу із зазначенням відповідальних виконавців та контролерів, засобів контролю, а також дій за допомогою автоматизованих технологічних, інформаційних систем. Часто як основа побудови таких схем використовуються надані підприємством дані внутрішнього контролю у вигляді графіків документообігу, особистих схем процесу, а також інформація за результатами проведення безпосередніх зустрічей із представниками менеджменту та працівниками, задіяними в окремих процесах.

Опис бізнес-процесу здійснюється разом із характеристикою внутрішнього контролю щодо них. На основі представлених схем визначаються слабкі місця у виконанні внутрішнього контролю, на яких може виникати ризик суттєвого викривлення інформації, що спричинить недостовірне подання фінансової звітності підприємством.

Аудитор спрямовує найбільші зусилля на перевірку внутрішнього контролю щодо бізнес-процесів та відповідних операцій, які пов'язані із ризиком суттєвого викривлення інформації, щоб забезпечити належні аудиторські докази. При цьому на наступному етапі виявлення ризиків суттєвого викривлення інформації щодо бізнеспроцесів має бути зроблено чітке розмежування між внутрішньо властивим ризиком і ризиком контролю.

Відповідно до МСА 315 “Ідентифікація та оцінювання ризиків суттєвого викривлення через розуміння суб'єкта господарювання і його середовища”, внутрішньо властивий ризик - це вразливість твердження щодо класу операцій, залишку рахунку або розкриття інформації до викривлення, яке може бути суттєвим окремо або в сукупності з іншими викривленнями, перед тим, як брати до уваги будь-які відповідні заходи контролю. Ризик контролю полягає в тому, що викривлення, яке може трапитися у твердженні стосовно класу операцій, залишку рахунку або розкриття інформації і яке може бути суттєвим окремо або в сукупності з іншими викривленнями, не буде своєчасно попереджено або виявлено та виправлено системою внутрішнього контролю суб'єкта господарювання [1, с. 100].

Після вивчення бізнес-процесів, виявлення ризиків та опису актуальних засобів контролю аудитор має перевірити адекватність розробки належних засобів контролю, а також визначити, чи працює контроль на підприємстві так, як це передбачено особами, які мають необхідні повноваження та компетенції для ефективного здійснення контролю, чи відповідає система внутрішнього контролю цілям підприємства і чи здатні засоби контролю ефективно запобігати або виявляти помилки й шахрайство, які можуть призвести до суттєвих викривлень у фінансовій звітності.

На підприємстві, як правило, застосовують такі види контролю як попередній і поточний. Попередній контроль виконується з метою запобігання помилкам та шахрайству, які можуть призвести до викривлень у фінансовій звітності. Зокрема, він може здійснюватися у вигляді процедур підтвердження, а саме: підприємство здійснює 
оплату рахунку лише в разі повної відповідності між даними в ньому і в замовленні на купівлю. Поточний контроль, наприклад щомісячна перевірка рахунків, спрямований на виявлення помилок або шахрайства, які вже відбулися і можуть призвести до викривлення фінансової звітності. При цьому процедури контролю на підприємстві можуть виконуватися автоматично або вручну, як на рівні підприємства, так і на рівні структурних підрозділів.

Найбільш важливе значення для аудиторської перевірки має прямий контроль на підприємстві та контроль нижчого рівня. Прямий контроль передбачає контрольні дії керівників структурних підрозділів на підприємстві, а непрямий контроль здійснюється через доведення до працівників підприємства відповідної розпорядчої документації щодо заходів контролю (рис. 2).

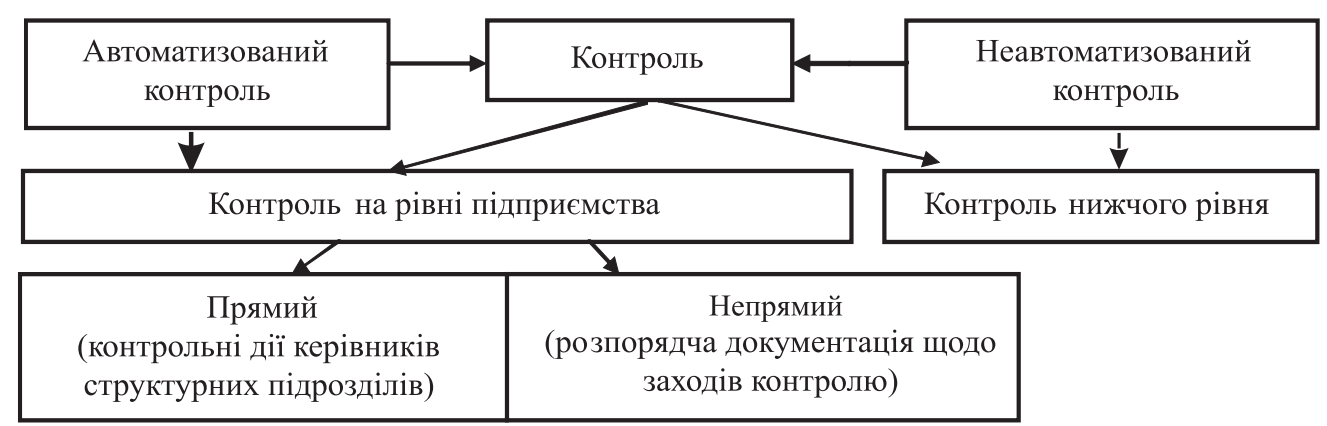

Рис. 2. Класифікація видів контролю на підприємстві

Джерело: складено авторами на основі [11, с. 19-20]

Тести на адекватність розробки внутрішнього контролю на підприємстві спрямовані на здійснення двох напрямів аудиторських дій та відповідного документування:

- отримання доказів належної розробки внутрішнього контролю на підприємстві за допомогою опитування, перевірки документації та спостереження, а також складання такої документації як опис системи внутрішнього контролю, блоксхем документообігу, анкет опитування тощо;

- оцінювання управління ризиками суб'єкта господарювання.

Опис системи внутрішнього контролю здійснюється як в цілому для підприємства, так і для окремих важливих бізнес-процесів.

Важливим для тестування адекватності розробки внутрішнього контролю на підприємстві $€$ питання "Чи можуть засоби внутрішнього контролю фактично запобігати або виявляти суттєві викривлення інформації в обліку та звітності підприємства?”, яке розглядається в таких аспектах:

- відповідність мети внутрішнього контролю, іiі співвідношення із ризиком та завданнями аудиторського судження;

- адекватність внутрішнього контролю з огляду на характер та значення, величину, суттєвість ризику;

- компетенції та повноваження осіб, що здійснюють внутрішній контроль;

- частота та послідовність здійснення внутрішнього контролю;

- рівень агрегації та передбачуваності даних, що підлягають контролю;

- $\quad$ критерії для розслідування та процесу подальшого спостереження;

- залежність від інших елементів управління або інформації для виконання внутрішнього контролю.

Після зазначених тестів проводиться оцінювання ризику внутрішнього контролю, тобто адекватності розробки належного внутрішнього контролю на підприємстві, результатом якого є оцінка імовірності того, що внутрішній контроль може бути неефективним.

За результатами оцінювання ризику внутрішнього контролю на адекватність розробки внутрішнього контролю проводиться планування суті, строків і кількості тестів операційної ефективності внутрішнього контролю. Такі тести включають отримання 
доказів того, що підприємство виконує контрольні дії і контроль здійснюється у передбачений спосіб. Слід відрізняти тест на адекватність розробки внутрішнього контролю від тесту на ефективність функціонування внутрішнього контролю: якщо тести на адекватність розробки спрямовані на перевірку здатності контролю запобігати або виявляти суттєві викривлення, то тест на ефективність функціонування - на перевірку здатності контролю виявляти викривлення інформації та шахрайство.

Дуже важливо планувати суть, строки і кількість тестів на ефективність функціонування внутрішнього контролю, оскільки в подальшому це вплине на обсяг процедур аудиторської перевірки, процедур по суті після стадії планування та оцінювання внутрішнього контролю.

Тестування на ефективність функціонування внутрішнього контролю на підприємстві здійснюється такими аудиторськими процедурами:

- $\quad$ спостереження - нагляд за процесом або процедурою, які виконують інші особи, наприклад спостереження аудитора за процесом інвентаризації, яку здійснює персонал суб'єкта господарювання;

- інспектування - вивчення записів або документів, внутрішніх чи зовнішніх, у паперовій, електронній або іншій формі, або фізичне вивчення активу шляхом інвентаризаційних перевірок;

- $\quad$ запит - пошук фінансової та нефінансової інформації від обізнаних осіб як усередині суб'єкта господарювання, так і за його межами. Аудитором також може проводитися процедура введення хибних даних в інформаційну систему підприємства для перевірки якості здійснюваного контролю на рівні програмного забезпечення;

- повторне виконання - незалежне виконання аудитором процедур або заходів внутрішнього контролю, які вже виконувались як частина заходів внутрішнього контролю суб'єкта господарювання.

Характер тестів на ефективність функціонування внутрішнього контролю значною мірою залежить від специфіки контролю, що підлягає перевірці, включаючи існування на підприємстві документального підтвердження виконання процедур контролю, оскільки в деяких випадках документального підтвердження наявності деяких елементів управління, таких як філософія управління та стиль роботи, може не бути.

Терміни тестування контролю залежать від часу, коли отримуються докази про операційну ефективність контролю, та періоду, до якого ці докази застосовуються. Аудитор повинен отримати докази того, що внутрішній контроль, обраний для оцінювання, розроблений адекватно та ефективно функціонує протягом періоду, який підлягає перевірці.

Суб’єкт господарювання може вносити зміни до засобів внутрішнього контролю для підвищення їх ефективності або для усунення виявлених недоліків контролю. У такому разі встановлюється, чи мали такі зміни позитивний вплив на внутрішній контроль протягом певного періоду часу. Для отримання більш переконливих аудиторських доказів щодо ефективності контролю доречним є збільшення обсягу тестування контролю.

При виявленні відхилень від розробленої системи внутрішнього контролю аудитор визначає вплив відхилень на оцінку контролю та отримані докази ефективності контролю.

Аудитор оцінює відхилення від розробленої системи внутрішнього контролю, щоб визначити наявність суттєвих недоліків внутрішнього контролю та повідомити про них керівництво та працівників підприємства, використовуючи при цьому професійні судження (рис. 3).

\begin{tabular}{|c|}
$\begin{array}{c}\text { Узагальнення виявлених } \\
\text { недоліків за результатами } \\
\text { оцінювання внутрішнього } \\
\text { контролю }\end{array}$ \\
$\begin{array}{c}\text { Оцінка виявлених } \\
\text { недоліків контролю на } \\
\text { суттєвість }\end{array}$
\end{tabular}$\rightarrow$\begin{tabular}{c}
$\begin{array}{c}\text { Повідомлення про недоліки у звіті } \\
\text { про ефективність функціонування } \\
\text { контролю }\end{array}$ \\
\hline
\end{tabular}

Рис. 3. Схема дій аудитора при виявленні відхилень від розробленої системи внутрішнього контролю на підприсмстві Джерело: розроблено авторами 
Відповідно до МСА 265 “Повідомлення інформації про недоліки внутрішнього контролю тим, кого наділено найвищими повноваженнями, та управлінському персоналу”, до письмового повідомлення інформації про значні недоліки внутрішнього контролю аудитор повинен включити:

- опис недоліків та пояснення їх потенційного впливу;

- інформацію, достатню для того, щоб надати можливість тим, кого наділено найвищими повноваженнями, та управлінському персоналу зрозуміти контекст повідомлення.

Зокрема, аудитор повинен пояснити, що:

- мета аудиту полягала в тому, щоб аудитор висловив думку щодо фінансової звітності;

- $\quad$ аудит охоплював розгляд внутрішнього контролю, важливого для складання фінансової звітності, щоб розробити аудиторські процедури, які $є$ прийнятними за конкретних обставин;

- п питання, про які йдеться, обмежуються тими недоліками, які аудитор виявив під час аудиту і які $є$ досить важливими, щоб заслуговувати на увагу тих, кого наділено найвищими повноваженнями [1, с. 266].

Якщо виявлені недоліки є суттєвими, зовнішній аудитор зобов'язаний передати інформацію про них керівництву і управлінському персоналу підприємства. При цьому рівень деталізації, з яким доцільно повідомляти про суттєві недоліки, $є$ питанням професійного судження аудитора.

Важливим моментом є підхід до документування результатів тестів контролю. Після перевірки ефективності функціонування внутрішнього контролю аудитор узагальнює докази та формує висновки у звіті про ефективність функціонування внутрішнього контролю на підприємстві.

У разі, якщо ризик внутрішнього контролю оцінений як максимальний, аудитор лише вказує, до яких бізнес-процесів та господарських операцій застосована така оцінка, при цьому підстави для оцінки не розкриваються аудитором. Якщо ризик контролю оцінений нижче за максимальний, аудитор має задокументувати усі докази справедливості такої оцінки. Поставлені завдання з перевірки внутрішнього контролю та ув'язка з ними відповідних тестів допомагають знизити ризик неадекватного застосування тестів і тлумачення отриманих доказів.

Висновки. Від оцінки розробки та операційної ефективності внутрішнього контролю суб'єкта перевірки, а також встановлених ризиків щодо окремих бізнеспроцесів залежить планування наступних аудиторських процедур по суті, їх обсяг та цілі й спрямованість проведення. Тестування внутрішнього контролю на підприємстві в аудиторській перевірці має ключове значення для оптимізації строків іiї проведення, підвищення ефективності та якості надання аудиторських послуг. Для забезпечення раціональної побудови процесу аудиту потрібно чітко дотримуватися встановленої методики оцінювання аудитором внутрішнього контролю на підприємстві. Тестуванню контролю передує етап розуміння аудитором бізнеспроцесів, ризиків та елементів контролю, які їм відповідають на підприємстві. Ефективно організована аудиторська перевірка внутрішнього контролю на підприємстві та відпрацьована методика його здійснення дають можливість оперативно виявляти відхилення та недоліки внутрішнього контролю й вживати відповідних заходів для запобігання їм.

\section{Список використаних джерел}

1. Міжнародні стандарти контролю якості, аудиту, огляду, іншого надання впевненості та супутніх послуг. Видання 2015 року. Частина 1 [Електронний ресурс]. URL: http://apu.com.ua/msa

2. Дорош Н. І. Оцінювання управління ризиками як функція внутрішнього ризикорієнтованого аудиту // Вісник Київського національного університету імені Тараса Шевченка. Економіка. 2017. Вип. 5(194). С. 13-21.

3. Савченко Р. О. Еволюція західної теорії внутрішнього контролю // Агросвіт. 2016. № 5. C. 29-32. 
4. Handbook of International Quality Control, Auditing, Review, Other Assurance, and Related Services Pronouncements: 2012 edition [Electronic resource]. URL : URL : http://www.ifac.org/

5. Internal Control: Integrated Framework - 2013 [Electronic resource]. URL: http:// www. coso.org/

6. Dittmeier Carolyn. Evaluating Internal Control Systems. A Comprehensive Assessment Model (CAM). Enterprise Risk Management Institute of Internal Auditors Research Foundation: Florida, 2014. 65 p.

7. Anderson Douglas J., Eubanks Gina. Leveraging COSO Across the Three Lines of Defense. Committee of Sponsoring Organizations of the Treadway Commission. 2015.32 p.

8. Guide to internal control over financial reporting. Center for audit quality. Washington, DC 2004. $16 \mathrm{p}$.

9. Graham Lynford. Internal Control Audit and Compliance: Documentation and Testing under the New COSO Framework. John Wiley \& Sons. Inc.: Hoboken. New Jersey. 2015. $416 \mathrm{p}$.

10. Graham Lynford. Internal Controls: Guidance for Private, Government, and Nonprofit Entities. John Wiley \& Sons. Inc.: Hoboken. New Jersey. 2008. 239 p.

11. Arwinge Olaf. Internal Control: A Study of Concept and Themes. Springer-Verlag: Berlin. Heidelberg. 2013. 189 p.

12. Risk Management \& Internal Control [Electronic resource]. URL: https://www.ifac.org/ global-knowledge-gateway/risk-management-internal-control?resources\&media=book

\section{References}

1. Mizhnarodni standarty kontroliu yakosti, audytu, ohliadu, inshoho nadannia vpevnenosti ta suputnikh posluh. Vydannia 2015 roku. Chastyna 1 [International standards on quality control, auditing, review, other assurance and related services. Edition 2015. Part 1]. Retrieved from http://apu.com.ua/msa [in Ukrainian]

2. Dorosh N. I. (2017). Otsiniuvannia upravlinnia ryzykamy yak funktsiia vnutrishnoho ryzyk-oriientovanoho audytu [Assessment of risk management: a function of the internal risk-oriented audit]. Visnyk Kyivskoho natsionalnoho universytetu imeni Tarasa Shevchenka. Ekonomika - Bulletin of Kyiv Nation Taras Shevchenko University, 5(194), 13-21 [in Ukrainian].

3. Savchenko R. O. (2016). Evoliutsiia zakhidnoi teorii vnutrishnoho kontroliu [Evolution of the Western theory of internal control]. Ahrosvit-Agroworld, 5, 29-32 [in Ukrainian].

4. Handbook of International Quality Control, Auditing, Review, Other Assurance, and Related Services Pronouncements: 2012 edition. Retrieved fromhttp: //www.ifac.org/

5. Internal Control: Integrated Framework - 2013. Retrieved from http://www. coso.org/

6. Dittmeier Carolyn (2014). Evaluating Internal Control Systems. A Comprehensive Assessment Model (CAM). Enterprise Risk Management Institute of Internal Auditors Research Foundation: Florida. 65 p.

7. Anderson Douglas J., Eubanks Gina (2015). Leveraging COSO Across the Three Lines of Defense. Committee of Sponsoring Organizations of the Treadway Commission. 32 p.

8. Guide to internal control over financial reporting. Center for audit quality. Washington, DC 2004. 16 p.

9. Graham Lynford (2015). Internal Control Audit and Compliance: Documentation and Testing under the New COSO Framework. John Wiley \& Sons. Inc.: Hoboken. New Jersey. $416 \mathrm{p}$.

10. Graham Lynford (2008). Internal Controls: Guidance for Private, Government, and Nonprofit Entities. John Wiley \& Sons. Inc.: Hoboken. New Jersey. 239 p.

11. Arwinge Olaf (2013). Internal Control: A Study of Concept and Themes. Springer-Verlag: Berlin. Heidelberg. 189 p.

12. Risk Management \& Internal Control. Retrieved from https://www.ifac.org/globalknowledge-gateway/risk-management-internal-control?resources\&media=book 
Н. И. ДОРОШ,

доктор экономических наук, профессор, профессор кафедры учета и аудита,

Киевский наџиональный университет имени Тараса Шевченко; М. О. ФЕСАЙ, магистрант,

Киевский национальный университет имени Тараса Шевченко

\section{Методологические аспекты оценки аудитором внутреннего контроля предприятия}

В статье раскрыты методологические аспекты оценивания аудитором внутреннего контроля на предприятии по стадиям аудиторского прочесса. Приведена методика аудита адекватности разработки эффективности функиионирования внутреннего контроля на предприятии по отдельным бизнес-процессам. Раскрыто значение внутреннего контроля отдельных бизнес-прочзессов предприятия. Показано влияние оценки внутреннего контроля на предприятии на планирование последующих аудиторских процедур по сути.

Ключевые слова: внутренний контроль на предприятии, бизнес-прочесс, адекватность разработки внутреннего контроля, эффективность функиионирования внутреннего контроля, финансовая отчетность, риск.

N. I. DOROSH,

Dsc (Economics), Professor, Professor of Accounting and Audit Department, Kyiv National Taras Shevchenko University; M. O. FESAI, Master's Student, Kyiv National Taras Shevchenko University

\section{Methodological Aspects of Evaluation of the Enterprise's Internal Control by the Auditor}

The article is devoted to the methodology for assessment of the internal control system at the enterprise by auditors, by addressing the following tasks: to determine the role of assessment of the internal audit at the enterprise in the auditing of financing reporting; to define business processes at the enterprise and the method for detecting the risks of essential distortions of risk-related information, and embed the means of control in the overall organization structure; to sum up the testing techniques involved in the internal control at the enterprise by showing the essence of testing for the adequacy of development and effectiveness of operation of the internal control at the enterprise; to show the impact of assessment of the internal control at the enterprise on the planning of auditor procedures in substance. Issues dealt with in the study include phases of financial reporting audit by business process, classification of types of control at the enterprise, the need to distinguish between the test for the adequacy of development of internal control and the test for the effectiveness of operation of the internal control etc. The auditor's actions in detecting deviations from the internal control system established at the enterprise are illustrated. The conclusion is made that a properly organized auditing of the internal control at the enterprise and welldesigned techniques of control enable for quick detecting of errors and drawbacks of the internal control and take relevant measure for their prevention.

Keywords: internal control at the enterprise, business process, adequacy of the development of internal control, effectiveness of the operation of internal control, financial reporting, risk.

\section{Посилання на статтю:}

Дорош Н. І., Фесай М. О. Методологічні аспекти оцінки аудитором внутрішнього контролю на підприємстві // Науковий вісник Національної академії статистики, обліку та аудиту: зб. наук. пр. 2018. №1-2. С. 68-76. 